\title{
PENINGKATAN KESADARAN HUKUM MASYARAKAT TERHADAP PENGATURAN HUKUM WARIS DI INDONESIA
}

\author{
Ida Kurnia ${ }^{1}$ dan Tundjung H.S. ${ }^{2}$ \\ ${ }^{1}$ Fakultas Hukum, Universitas Tarumanagara \\ Email: idah@fh.untar.ac.id \\ ${ }^{2}$ Fakultas Hukum, Universitas Tarumanagara \\ Email: tundjunghidayat@yahoo.com
}

\begin{abstract}
ABSTRAK
Dalam perspektif substansi hukum pengaturan sistem kewarisan nasional terbagi dalam kewarisan barat, kewarisan adat, dan kewarisan Islam. Pengaturan kewarisan dapat dipandang memadai dalam mengatasi masalah kewarisan yang terjadi di Indonesia. Namun dalam tataran implementasi terdapat kendala yang disebabkan oleh rendahnya kualitas kesadaran hukum masyarakat terhadap sistem kewarisan yang ada. Problematika kesadaran hukum merupakan suatu permasalahan yang terjadi di Indonesia. Rendahnya kesadaran hukum masyarakat diketahui dengan melihat beberapa indikator antara lain pengetahuan masyarakat terhadap suatu aturan hukum, pengetahuan masyarakat terhadap isi dari aturan hukum dan sikap masyarakat terhadap hukum, dan lain sebagainya. Hal inilah yang juga terjadi pada masyarakat di Kelurahan Tanjung Duren Utara, Kecamatan Grogol Petamburan Kota Administrasi Jakarta Barat Provinsi DKI Jakarta. yang belum memiliki pengetahuan yang memadai perihal sistem hukum kewarisan yang terdapat di Indonesia. Terlebih kondisi saat ini menunjukkan adanya keragaman sistem kewarisan. Keadaan yang demikian tentu perlu diatasi melalui suatu proses pembinaan kesadaran hukum waris yang dapat dilakukan melalui suatu kegiatan pengabdian masyarakat yang membuka ruang untuk berdiskusi perihal sistem pewarisan yang berlaku di Indonesia. Kesimpulan dari pelaksanaan PKM ini bahwa

terdapat masalah dalam konteks pelaksanaan sistem kewarisan yang saat ini mengacu pada hukum waris barat, hukum waris adat, dam hukum waris Islam. Masalah tersebut muncul karena proses sosialisasi, pembinaan, dan pendidikan di bidang kewarisan terhadap masyarakat selaku pengguna hukum waris tidak dilakukan sehingga masyarakat tidak mendapatkan pemahaman yang memadai mengenai hukum waris.
\end{abstract}

Kata kunci: hukum waris; sistem kewarisan; kesadaran hukum.

\section{PENDAHULUAN}

Mewaris adalah menggantikan hak dan kewajiban seseorang yang meninggal. Pada umumnya yang digantikan adalah hanya hak dan kewajiban di bidang hukum kekayaan saja. Fungsi dari yang mewariskan yang bersifat pribadi atau yang bersifat hukum keluarga (misalnya suatu perwalian) tidaklah beralih (H.F.A. Vollmar:1989). Aturan hukum yang mengatur mengenai mewaris disebut hukum waris. Di Indonesia aturan hukum waris terdapat berbagai sistem, sistem waris barat, sistem waris agama dan sistem waris adat.

Terkait dengan kondisi tersebut Bagir Manan menyatakan bermacam-macam hukum kewarisan tersebut walau tanpa kodifikasi, tanpa unifikasi, tidak berarti tidak aka nada hukum nasional. Keanekaragaman hukum, bukanlah sesuatu yang perlu dihindari, sepanjang tidak dimaksudkan untuk member privilege atau sebaliknya untuk merendahkan suatu kelompok. Keragaman hukum justru dapat bermanfaat dalam membangun kesatuan dan harmonisasi hubungan antar kelompok karena masing-masing merasa dihargai dan diberi tempat yang wajar dan masuk akal dalam tata kehidupan bersama, disamping itu juga dalam rangka mengakomodir landscape masyarakat Indonesia yang sangat pluralistic secara sosiologis (Bagir Manan: 2009).

Pertama sistem hukum waris adat, Sistem hukum warisan adat di Indonesia dipengaruhi oleh prinsip garis kekerabatan. Disampaikan oleh Kuntjaraningkrat, terdapat empat prinsip pokok garis keturunann (princeple decent) di Indonesia, yaitu: Prinsip Patrilinel (Patrilineal Decent) yang menghitung hubungan kekerabatan melalui laki-laki saja, dan karena itu mengakibatkan bahwa tiap individu dalam masyarakat semua kaum kerabat ayah masuk ke dalam batas hubungan 
kekerabatannya, sedang kaun kerabat itu jatuh di luar batas itu; Prinsip Matrilineal (Matrilineal Decent), yang menghubungkan hubungan kekerabatan melalui perempuan saja, dan karena itu mengakibatkan bahwa tiap-tiap individu dalam masyarakat semua kerabat ibu dalam batas hubungan kekerabatannya, sedang kaum kerabat ayah jatuh di luar batas itu; Prinsip Bilineal (Bilineal Decent) prinsip ini juga sering disebut doble decent, yang menghitungkan hubungan kekerabatan melalui pria saja, untuk sejumlah hak dan kewajiban tetentu, dan melalui wanita saja untuk sejumlah hak dan kewajiban yang lain, dan karena mengakibatkan bahwa bagi tiap-tiap individu dalam masyarakat kadang-kadang semua kaum kekerabatan ayah masuk ke dalam batas hubungan kekerabatannya, sedangkan kaum kerabat ibu jatuh di laur batas itu, dan kadang-kadang sebaliknya; Prinsip Bilateral (Bilateral Decent) yang menghitungkan hubungan keturunan melalui ayah dan ibu (Kuntjaraningrat: 1992).

Kedua, Sistem Hukum Waris Barat, A. Pitlo mengemukakan hukum waris adalah Kumpulan peraturan yng mengatur hukum mengenai kekayaan karena wafatnya seseorang, yaitu mengenai perpindahan kekayaan yang ditinggalkan oleh di mati dan akibat dari hubungan antara mereka dengan mereka, maupun dalam hubungan antara mereka dengan pihak ketiga (Pitlo: 1986). Pengertian lainnya disampaikan oleh Wirjono Prodjodikoro bahwa hukum waris adalah hukumhukum atau peraturan-peraturan yang mengatur tentang apakah dan bagaimanakah berbagai hakhak dan kewajiban tentng kekayaan seseorang pada waktu ia meninggal dunia akan beralih kepada orang lain yang masih hidup (M. idris Ramulyo: 2004).

Ketiga, sistem hukum kewarisan islam, Hukum kewarisan Islam merupakan nilai-nilai agama Islam yang telah diyakini umatnya, kemudian dijadikan sistem kehidupan untuk mengatur hubungan sesama manusia, yang selanjutnya menjadi sistem hukum kewarisan. Agama Islam merupakan mayoritas agama yang dianut oleh warga negara Indonesia, maka sistem hukum kewarisan Islam menjadi salah satu sistem hukum yang berlaku di Indonesia (Komari: 2011).

Banyaknya sistem hukum waris tersebut menjadi indikator masyarakat membutuhkan/memerlukan informasi, pengetahuan hukum kewarisan dan perlindungan terhadap hak waris sebagai ahli waris. Tujuannya adalah untuk menyelesaikan dan mengurus harta warisan milik pewaris berisikan hak-hak dan kewajiban-kewajiban akan diterima dan dijalankan oleh perwakilan ahli waris/ahli waris berdasarkan kesepakatan serta dibagikan kepada ahli waris adalah ahli waris yang mempunyai hak waris. Mengingat ada tiga macam sistem hukum kewarisan yaitu perdata barat, adat, dan Islam, maka dalam pengabdian yang akan dilakukan di Kelurahan Tanjung Duren Utara, Kecamatan Grogol Petamburan Kota Administrasi Jakarta Barat, lebih dispesifikasikan pada Pengaturan Sistem Kewarisan Dalam Hukum Nasional dan Implementasinya. Pemilihan ini didasarkan pada observasi tentang adanya keluhan-keluhan dari anggota masyarakat tersebut dalam sistem pembagian kewarisan.

\section{METODE PELAKSANAAN PKM}

Pada saat kegiatan pengabdian kepada masyarakat, ceramah digunakan untuk menginformasikan perihak kebijakan dan regulasi yang terkait berbagai sistem hukum waris di Indonesia. Pemilihan metode ceramah dikarenakan peserta pengabdian kepada masyarakat yang banyak jumlahnya dan para peserta tidak mengetahui aturan yang lengkap mengenai hukum waris yang berlaku di Indonesia. Pada sesi ceramah para pelaksana PKM menyampaikan materi antara lain: sistem hukum waris barat, sistem hukum waris adat dan sistem hukum waris islam.

Setelah sesi ceramah, pada saat pengabdian masyarakat dibuat sesi Q \& A. pada sesi ini peserta pengabdian kepada masyarakat dapat mengajukan pertanyaan-pertanyaan yang kemudian akan 
dijawab oleh pelaksana PKM. Selain itu, peserta dapat pula memberikan informasi atau pengalaman seputar pembagian waris yang telah dilakukan. Sesi ini dibuka sebanyak 3 (tiga) kali dengan masing-masing sesi dapat menerima 5 pertanyaan

\section{HASIL DAN PEMBAHASAN}

Di Indonesia masih terdapat beraneka sistem hukum kewarisan (belum adanya unifikasi hukum) yang berlaku bagi warga Negara Indonesia yaitu: Pertama, Sistem Hukum Kewarisan Perdata Barat (Eropa), yang tertuang dalam Burgerlijk Wetboek (Kitab Undang-Undang Hukum Perdata) disingkat KUHPer yang berdasarkan ketentuan Pasal 131 I.S jo. Staatsblad 1917 Nomor 129 jo. Staatsblad 1924 Nomor 557, jo. Staatsblad 1917 nomor 12 tentang Penundukkan Diri terhadap Hukum Eropa, maka BW tersebut berlaku bagi: Orang-orang Eropa dan mereka yang dipersamakan dengan orang Eropa; Orang Timur Asing Tionghoa; dan Orang Timur Asing lainnya dan orang-orang Indonesia yang menundukkan diri kepada Hukum Eropa. Kedua, Sistem Hukum Kewarisan Adat yang beraneka ragam pula sistemnya yang dipengaruhi oleh bentuk etis di berbagai daerah lingkungan hukum adat, misalnya sistem unilateral matrilinial di Minangkabau, patrilinial di Batak, bilateral atau parental di Jawa, alternerend unilateral (sistem unilateral yang beralih-alih) seperti di Rejang Lebong atau Lampung Papadon, yang diperlakukan kepada orangorang Indonesia yang masih erat hubungannya dengan masyarakat hukum adat yang bersangkutan. Ketiga, Sistem Hukum Kewarisan Islam, yang juga terdiri pluralism ajaran, seperti ajaran Kewarisan Ahlul Sunnah Wal Jamaah, ajaran Syi'ah, ajaran Hazairin yang paling dominan dianut di Indonesia ialah ajaran Ahlul Sunnah Wal Jamaah (Mazhab Syafi'i, Hanafi, Hambali, dan Maliki tetapi yang paling dominan pula di antara ajaran 4 (empat) mazhab tersebut di Indonesia dianut ajaran Syafi'i disamping ajaran Hazairin. Hukum kewarisan ini berlaku bagi orang-orang Indonesia yang beragama Islam.

Ragam dan kompleksitas aturan di bidang hukum waris menjadi dasar perlunya diadakan peningkatan kesadaran hukum masyarakat melalui kegiatan pengabdian kepada masyarakat. Oleh karena itu para warga di Kelurahan Tanjung Duren Utara, Kecamatan Grogol Petamburan Kota Administrasi Jakarta Barat perlu diingatkan, diarahkan, disosialisasikan dan diberikan informasi dan pengetahuan tentang: pertama, apakah yang akan terjadi dengan hubungan hukum yang sudah dilakukan oleh pewaris? Ke-dua, bagaimana penyelesaian dan pengurusan hak-hak dan kewajibankewajibannnya oleh ahli waris terhadap seseorang yang meninggal dunia terhadap harta warisan dengan menerapkan prinsip-prinsip hukum waris?

Proses sosialisasi, pembinaan dan pendidikan ini diberikan dalam rangka untuk melindungi masyarakat dan khususnya melindungi ahli waris supaya tidak salah dalam menetapkan ahli waris dan tetap mendapatkan haknya, yaitu hak waris berupa uang ataukah benda bergerak ataukah benda tetap. Dalam hal ini anggota masyarakat atau khususnya anggota keluarga pewaris perlu mendapatkan pemahaman sesuai aturan hukum nasional, yaitu kesadaran, pengetahuan, dan pemahaman terhadap isi hukum kewarisan (hak-hak dan kewajiban-kewajiban pewaris dan ahli waris).

Dalam tataran hukum, peraturan tentang sistem kewarisan sudah ada dan jelas, tetapi dalam implementasinya tidak sesuai yang diharapkan, karena dipicu oleh berbagai faktor, antara lain: pembagian harta warisan yang dilakukan tidak transparan, ahli waris tidak mengetahui akan hakhak dan kewajiban-kewajibannya. Berdasarkan hal tersebut di atas dan hasil pengamatan yang telah dilakukan, maka daerah Kelurahan Tanjung Duren Utara, Kecamatan Grogol Petamburan Kota Administrasi Jakarta Barat sangat potensial untuk dilakukan sosialisasi, pembinaan dan pendidikan mengenai Hukum Waris di Indonesia Dan Permasalahannya. Sasaran ini akan lebih 
dispesifikasikan kepada para Kepala Warga dan ibu-ibu kelompok PKK, Karang Taruna serta warga yang mempunyai permasalahan dengan topik pengabdian ini di Kelurahan Tanjung Duren Utara, Kecamatan Grogol Petamburan Kota Administrasi Jakarta Barat. Gambar 1, merupakan pelaksanaan sosialiasi, pembinaan dan pendidikan hukum waris.

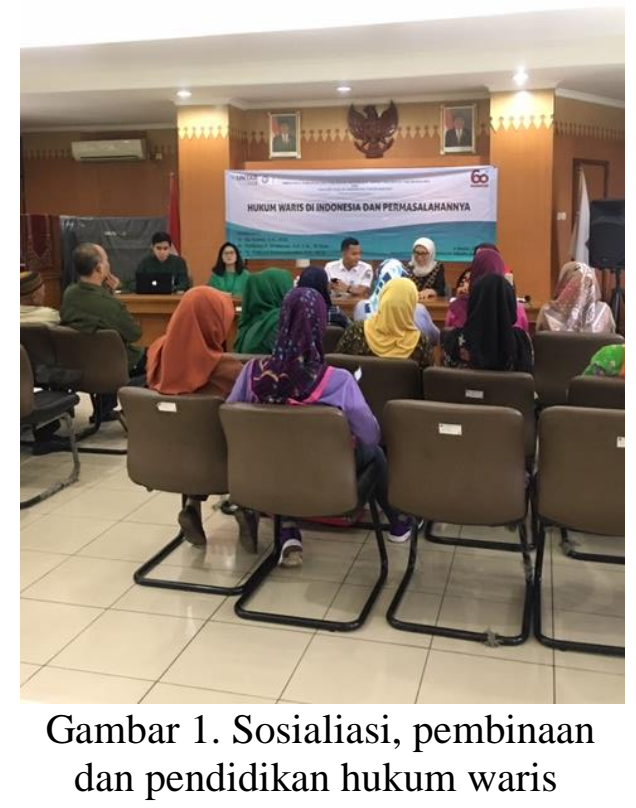

Proses sosialisasi, pembinaan dan pendidikan ini diperlukan agar ahli waris dapat mengetahui akan hak-hak dan kewajiban-kewajibannya, sehingga apabila seseorang meninggal dunia dan diikuti dengan perpindahan harta warisan kepada ahli waris. Oleh karena itupara Kepala Warga dan ibuibu yang tergabung dalam kelompok PKK, Karang Taruna, serta warga yang mempunyai permasalahan dengan topik pengabdian ini di Kelurahan Tanjung Duren Utara, Kecamatan Grogol Petamburan Kota Administrasi Jakarta Barat, perlu memahami permasalahan tersebut. Gambar 2 merupakan bagian dari sesi sosialisasi, yaitu tanya jawab tentang hukum waris.

Proses sosialiasi, pembinaan dan pendidikan mengenai hukum waris yang dilakukan dalam rangka mengatasi problem kesadaran hukum yang lemah. Dimana masyarakat mengakui tidak memiliki informasi dan pengetahuan yang baik terhadap hukum positif berkenaan dengan hukum waris. Ketidaktahuan tersebut dalam prespektif teori kesadaran hukum menurut Kutschinky merupakan indikator untuk menilai adanya masalah kesadaran hukum. Menurut Kutschinky (Soerjono Soekanto: 1982), indikator-indikator dari masalah kesadaran hukum dapat dilihat dari beberapa hal, antara lain Pengetahuan tentang peraturan-peraturan hukum (law awareness); Pengetahuan tentang isi peraturan-peraturan hukum (law acquaintance); Sikap terhadap peraturan-peraturan hukum (legal attitude); dan Pola-pola perikelakuan hukum (legal behaviour). 


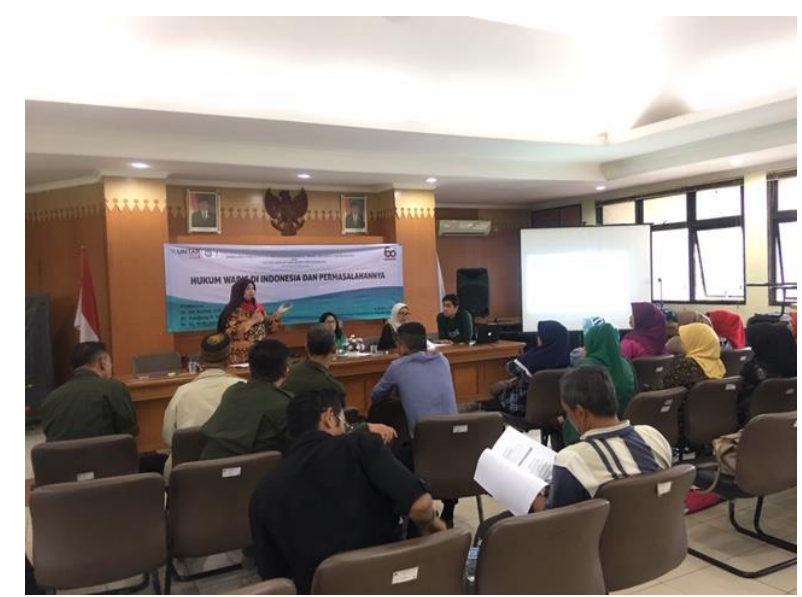

Gambar 2. Sesi tanya jawab hukum waris

\section{KESIMPULAN}

Berdasarkan pembahasan di atas maka dapat ditarik kesimpulan bahwa terdapat masalah dalam konteks pelaksanaan sistem kewarisan yang saat ini mengacu pada hukum waris barat, hukum waris adat, dam hukum waris Islam. Permasalahan tersebut lebih disebabkan oleh lemahnya kesadaran hukum masyarakat berkenaan dengan dasar pengaturan sistem kewarisan yang berlaku dan pemahaman terhadap substansi dari norma yang ada. Masalah tersebut muncul karena proses sosialisasi, pembinaan, dan pendidikan di bidang kewarisan terhadap masyarakat selaku pengguna hukum waris tidak dilakukan sehingga masyarakat tidak mendapatkan pemahaman yang memdai mengenai hukum waris.

\section{Ucapan Terimakasih}

Ucapan terimakasih kepada Direktorat Penelitian dan Pengabdian Kepada Masyarakat Universitas Tarumanagara atas pendanaan kegiatan pengabdian kepada masyarakat yang telah diberikan. Selain itu ucapan terimakasih juga diberikan kepada Camat Kecamatan Grogol Petamburan.

\section{REFERENSI}

H.F.A Vollmar. (1989). Pengantar Studi Hukum Perdata. Jakarta: Rajawali.

H. Hilman Hadikusumo (1990). Hukum Perkawinan Indonesia. Bandung: CV Mandar Maju Bagir Manan, Menuju Hukum Waris Nasional,yang disampaikan dalam Simposium tentang Menuju Surat Keterangan Waris Yang Bersifat Nasional bagi WNI, yang di selenggarakan oleh BPHN bekerjasama dengan Ikatan Keluarga Alumni NotariatUNPAD di Jakarta, pada tgl 6 Mei 2009.

Kuntjaraningrat. (1992). Beberapa Pokok Antropologi. Jakarta: Dian Rakyat.

A. Pitlo. (1986). Hukum Waris Menurut Kitab Undang-Undang Hukum Perdata Belanda. Jakarta: PT Intermasa.

M. Idris Ramulyo. (2004). Perbandingan Hukum Kewarisan Islam dengan Kewarisan Kitab Undang-Undang Hukum Perdata. Jakarta: Sinar Grafika.

Komari. (2011). Laporan Akhir Bidang Hukum Waris. Badan Pembinaan Hukum Nasional. Puslitbang. Jakarta.

Soerjono Soekanto. (1982). Kesadaran Hukum dan Kepatuhan Hukum. Jakarta: CV Rajawali. 